\title{
The Effect of Insulin-Like Growth Factor-I of Pregnant Crossbred Mare Serum and Insulin-Like Growth Factor-\| Recombinant Mouse on Estrous Cycles and Litter Sizes of Mice (Mus musculus)
}

\section{Tjuk Imam Restiadi, Imam Mustofa, Suzanita Utama, and Sri Mulyati}

Department of Veterinary Reproduction, Faculty of Veterinary Medicine, Universitas Airlangga - Surabaya 60115

\section{Abstract}

The research was conducted to determine the effect of insulin-like growth factor-I (IGF-I) derived from pregnant crossbred mare serum (PMS) on estrous cycle and litter

Corresponding Author: Tjuk Imam Restiadi tjukir@yahoo.com

Received: 03 October 2017 Accepted: 10 October 2017 Published: 29 November 2017

Publishing services provided by Knowledge $\mathrm{E}$

(c) Tjuk Imam Restiadi et al. This article is distributed under the terms of the Creative Commons Attribution License, which permits unrestricted use and redistribution provided that the original author and source are credited.

Selection and Peer-review under the responsibility of the VMIC Conference Committee. size in mice (Mus musculus). The research was arranged by Completely Randomized Design (CRD) with seven treatments and five replications. The treatments were control $(\mathrm{CO})=$ physiological $\mathrm{NaCl}$, treatment $(\mathrm{T}) 1=10 \mathrm{ng} / \mathrm{ml}$ of IGF-I pregnant mares crossbred serum (PMS), T2 $=20 \mathrm{ng} / \mathrm{ml}$ of IGF-I PMS, T3 $=40 \mathrm{ng} / \mathrm{ml}$ of IGF-I PMS, T4 = $10 \mathrm{ng} / \mathrm{ml}$ of IGF-I recombinant mouse, $T_{5}=20 \mathrm{ng} / \mathrm{ml}$ of IGF-I recombinant mouse, and T6 $=40 \mathrm{ng} / \mathrm{ml}$ of IGF-I recombinant mouse. Serie I the subject of this research were 35 female mice. Observed variables included estrous cycle phases that proestrus, estrus, metestrus, and diestrus phase. Serie II for the objects of this research were 35 female mice and 21 male mice in the same treatment on litter size in mice. The data were analyzed by Analysis of Variance (ANOVA), followed by HSD (Honestly Significant Difference) test. The result showed that the addition of IGF-I PMS did not significantly affect ( $p>0.05$ ) on proestrus, metestrus, and diestrus phase. The addition of IGF-I PMS $40 \mathrm{ng} / \mathrm{ml}$ was extended $(p<0.05)$ the estrus phase. It showed that there was not significantly difference ( $p>0.05$ ) between the effect of IGF-I PMS and IGF-I recombinant mouse with the mice estrous cycles. The result of IGF-I derived from PMS and IGF-I recombinant mouse on litter size in mice did not significantly difference ( $p>0.05$ ). Test results shows significant differences between control and $40 \mathrm{ng} / \mathrm{ml}$ of IGF-I PMS.

Keywords: IGF-I, IGF-I pregnant crossbred mare serum, estrous cycle, litter sizes, Mus musculus.

\section{S OPEN ACCESS}




\section{Introduction}

Insulin-like growth factor-I (IGF-I) is one of bioactive material, a supplementation of IGF-I in maturation and culture medium can stimulate and increase the number of oocyte. Besides, it also can increase the result of in vitro fertilization (IVF) and the amount of some livestock's embryo, such as pigs [1], cows [2], and buffaloes [3], which run into blastocyst. The addition of IGF-I during pig's prenatal follicle culture can enlarge the diameter of follicle. Meanwhile, mRNA insulin-like growth factor receptor-I (IGFR-I) can be increased by adding FSH supplementation as far as the culture and oocyte are able to do meiosis process after maturation [4]. One of the most important aspects in animal reproduction is estrus cycle. Monitoring this cycle plays an important role for fertilization and reproduction as it increases the number of animal population [5].

Nowadays, many researchers use bioactive to observe its effect toward estrous cycle which purposes to maintain the estrous cycle itself. One of bioactive material that has important role in reproduction is insulin-like growth factor-I (IGF-I). IGF-I is involved in increasing the proliferation of endometrium stromal cell of adult mice [6]. [7] who quoted from many resources stated that IGF-I is a factor which control the follicle and embryo growth. The quality of oocyte and embryo, result of superovulation, totally depend on IGF-I concentration [8]. In vivo, IGF-I concentration in the follicle of cow's superovulation can increase the number of embryo [9]. [10] and [11] stated that the addition of IGF-I into medium culture make the blastocyst percentage and embryo resistance of heat stresses work up. Besides, IGF-I is able to increase the number of lactating Cows pregnancy. Estrous cycle is one of important aspect in animal reproduction. Monitoring to this cycle will improve the success of animal fertilization and reproduction in order to increase the number of animal population [5].

Adding the insulin-like growth factor-I and insulin-like growth factor binding protein3 can fasten the puberty of female mice and increase the number of offspring [12]. When the puberty is about to come, FSH in blood will increase and cause the process of steroidogenesis and folliculogenesis. Steroidogenesis occurs in follicle cell; it is influenced by LH and assisted by IGF-I and IGFBP. This process forms androstenedione and testosterone. They will get into granulose cells from follicle to be converted into estradiol $17 \beta$ through the process of aromatization which is influenced by FSH and assisted by IGF-I and IGFBP. The increasing of estradiol $17 \beta$ secretion by granulose cells that is about to get ovulation causes the emergence of lust symptoms. Also, it will stimulate the high rates of $\mathrm{LH}$ which cause the ovulation and the emergence of ovum. The success of fertilization and embryo formation can be determined from the number of ovulation; the escalation of the amount of ovulated egg cells and converge 
to spermatozoa which will produce more fetus [13]. [14] found that, for some species, IGF-I escalates ovary activity by stimulating granulosa cells, theca cells, and mitogenesis proliferation. IGF-I synergy with gonadotropin in stimulating steroidogenesis [15]. stated that IGF-I concentration during the end of puberty (shortly before the first proestrus) can advance the puberty on mice. Besides, IGF-I in pre-puberty can advance puberty on primates as well.

According to the introduction above, this research is applied on mice by giving insulin-like growth factor-I (IGF-I) pregnant crossbred mare serum (PMS) in which its effect will be observed toward the estrous cycle and the amount of mice litter. This biopotency test is also purposed to comparing the differences between the effect of giving IGF-I PMS and the effect of giving IGF-I recombinant mouse.

\section{Materials and methods}

This research was conducted in Obstetric Veterinary Laboratory, Veterinary Reproduction Department, Faculty of Veterinary Medicine, Universitas Airlangga and Veterinary Observation Laboratory during October 2015 until December 2015. The effect of insulinlike growth factor-I (IGF-I) in lust cycle is mice strain Balb/C aged 35 days (under puberty) and the weight are the same. The mice were obtained from Farm Veterinary Center Surabaya. Meanwhile, the objects for the effect of IGF-I on the amount of mice litter acquisition were 35 female mice aged 30-35 days and 21 male mice aged 2 months, and they were adapted for seven days.

Female mice were injected subcutaneously by IGF-I pregnant crossbreed mare serum (PMS). The result of separation method Sodium Duodecyl SulphatePolyacrilamide Gel Electrophoresis (SDS-PAGE) and Western Blot examination. IGF-I was separated from the result by using elution method. It could be obtained that eluate IGF-I PMS and eluate IGF-I level are determined by sandwich ELISA [16], and IGF-I recombinant mouse, Cat\#591406, Biolegend, San Diego, USA).

\subsection{Dose determination}

IGF-I dose, based on [17] research, is $10 \mathrm{~g} / \mathrm{ml}$ which subcutaneously give significant result in enhancing bone resorption. It aims to maintain normal bone mass and to stimulate osteoclastogenesis on mice. On the other hand [18], added IGF-I dose: 5 $\mathrm{ng} / \mathrm{ml}, 10 \mathrm{ng} / \mathrm{ml}$, and $20 \mathrm{ng} / \mathrm{ml}$ on morula growth from oocyte culture of prenatal sheep 
follicle. This research is using IGF-I PMS and IGF-I recombinant mouse $10 \mathrm{ng} / \mathrm{ml}, 20$ $\mathrm{ng} / \mathrm{ml}$, and $40 \mathrm{ng} / \mathrm{ml}$ doses for each.

\subsection{Examined animal treatment}

Mice were injected by single dose IGF-I in the first day after seven days adaptation. The procedure for serie I was injecting per subcutaneous mice in control (C) o: physiological $\mathrm{NaCl}$, treatment (T) 1: $10 \mathrm{ng} / \mathrm{ml}$ IGF-I PMS, T2: $20 \mathrm{ng} / \mathrm{ml}$ IGF-I PMS, T3: $40 \mathrm{ng} / \mathrm{ml}$ IGF-I PMS, T4: $10 \mathrm{ng} / \mathrm{ml}$ IGF-I recombinant mouse, T5: $20 \mathrm{ng} / \mathrm{ml} \mathrm{IGF-I} \mathrm{recombinant} \mathrm{mouse,}$ and T6: $40 \mathrm{ng} / \mathrm{ml} \mathrm{IGF-I} \mathrm{recombinant} \mathrm{mouse.} \mathrm{The} \mathrm{observation} \mathrm{of} \mathrm{estrous} \mathrm{cycle} \mathrm{was}$ regularly done every six hours for 10 days ( 2 periods of mice lust cycle normally) in which there were 4 times inspections at $04.00 \mathrm{AM}, 10.00 \mathrm{AM}, 16.00 \mathrm{PM}$, and 22.00 PM. This observation is using vaginal smear as the method. Prepare vaginalsmear with Giemsa staining, then observed by using microscope with 100-400x magnification to determine the mice estrous cycle phases: proestrus, estrus, metestrus, or diestrus [19].

Serie II was treated, like seri I, by giving the dose as follows: Co: physiological $\mathrm{NaCl}$, T1: $10 \mathrm{ng} / \mathrm{ml}$ IGF-I PMS, T2: $20 \mathrm{ng} / \mathrm{ml} \mathrm{IGF-I} \mathrm{PMS,} \mathrm{T3:} 40 \mathrm{ng} / \mathrm{ml} \mathrm{IGF-I} \mathrm{PMS,} \mathrm{T4:} 10 \mathrm{ng} / \mathrm{ml}$ IGF-I recombinant mouse, T5: $20 \mathrm{ng} / \mathrm{ml}$ IGF-I recombinant mouse, and T6: $40 \mathrm{ng} / \mathrm{ml} \mathrm{IGF-}$ I recombinant mouse per subcutaneous. The injected female mice were gathered with male mice (ratio 5:3) during one lust cycle. The observation would be done until the female mice bear the offsprings in one pregnancy period and they would be counted ( \pm 21 days).

\subsection{The calculation of lust cycle phase period}

The frequency of estrous phase will be converted as the period of estrous cycle [19]. The function as follows:

$$
X=\frac{A \times Y}{B}
$$

Note: $X$ : estrous phase period (hour),

$Y$ : examination period (hour)

A: frequency of each phase in one sample

B: frequency total of all phases 
TABLE 1: Data of vaginal smear results on mice estrous cycle after given IGF-I PMS (hour).

\begin{tabular}{|c|c|c|c|c|}
\hline \multirow[t]{2}{*}{ Treatment } & \multicolumn{4}{|c|}{ Estrous Cycle $(x \pm S D)$} \\
\hline & Proestrus & Estrus & Metestrus & Diestrus \\
\hline Co & $12.60^{a} \pm 3.91$ & $14.40^{a b} \pm 3.91$ & $28.20^{a} \pm 6.57$ & $64.80^{a} \pm 6.90$ \\
\hline T1 & $5.40^{a} \pm 4.44$ & $3.00^{a} \pm 4.24$ & $24.60^{a} \pm 21.88$ & $87.00^{a} \pm 27.90$ \\
\hline $\mathrm{T} 2$ & $8.40^{a} \pm 6.84$ & $4.20^{a} \pm 4.02$ & $16.80^{a} \pm 18.68$ & $90.60^{a} \pm 25.04$ \\
\hline$T_{3}$ & $10.20^{a} \pm 6.90$ & $24.00^{b} \pm 14.07$ & $28.20^{a} \pm 20.30$ & $58.20^{a} \pm 32.62$ \\
\hline
\end{tabular}

\subsection{Design of the Study}

This research uses Completely Randomized Design (CRD). The conducted data, after given IGF-I PMS and IGF-I recombinant mouse, would be analyzed by using ANOVA (Analysis of Variance) examination and statistical program by using software SPSS 21 (Statistical Product and Service Solution 21). If there is significant difference $(p<0.05)$, then continue it with Honestly Significant Different (HSD) examination [21]. The analysis was used to compare two treatment factors: IGF-I PMS and IGF-I, by using General Linear Model Univariate.

\section{Results}

\subsection{The effect of IGF-I PMS and IGF-I recombinant mouse on mice estrous cycle}

The result of vaginal smear on mice estrous cycle after given IGF-I PMS will be presented in Table 1.

Based on the result of mice's vaginal smear in estrous cycle after given IGF-I PMS, it shows that there is difference in this phase. Yet, giving IGF-I PMS does not cause significant difference ( $p>0.05$ ) from the period of proestrus, metestrus, and diestrus phase in the treatments of $T_{1}, T_{2}$, and T3lGF-I PMS in the doses of $40 \mathrm{ng} / \mathrm{ml}$ and $\mathrm{T}_{3}$ treatment leads estrous phase get longer significantly $(p<0.05)$. The result of mice's vaginal smear in estrous cycle after given IGF-I recombinant mouse is presented in Table 2.

Adding IGF-I recombinant mouse gives an effect on mice's estrous cycle. Various doses of IGF-I recombinant mouse does not show significant difference ( $p>0.05$ ) from the period of proestrus and estrous phase in the treatment of $T_{4}, T_{5}$, andT6. IGF-I 
TABLE 2: Data of vaginal smear result on mice estrous cycle after given IGF-I recombinant mouse (hour).

\begin{tabular}{|c|c|c|c|c|}
\hline \multirow[t]{2}{*}{ Treatment } & \multicolumn{4}{|c|}{ Estrous Cycle $(x \pm S D)$} \\
\hline & Proestrus & Estrous & Metestrus & Diestrus \\
\hline Co & $12.60^{a} \pm 3.91$ & $14.40^{a} \pm 3.91$ & $28.20^{a b} \pm 6.57$ & $64.80^{a b} \pm 6.90$ \\
\hline T4 & $7.80^{a} \pm 5.40$ & $6.60^{a} \pm 13.14$ & $14.40^{a} \pm 9.81$ & $97.20^{b} \pm 13.51$ \\
\hline T5 & $4.20^{a} \pm 7.82$ & $22.80^{a} \pm 17,80$ & $43.20^{b} \pm 25.94$ & $49.80^{a} \pm 40.72$ \\
\hline T6 & $3.00^{a} \pm 3.00$ & $6.60^{a} \pm 4.44$ & $12.00^{a} \pm 6.70$ & $98.40^{b} \pm 4.44$ \\
\hline
\end{tabular}

TABLE 3: Data of period comparison on mice estrous cycle after given IGF-I PMS and IGF-I recombinant mouse in each phase (hour).

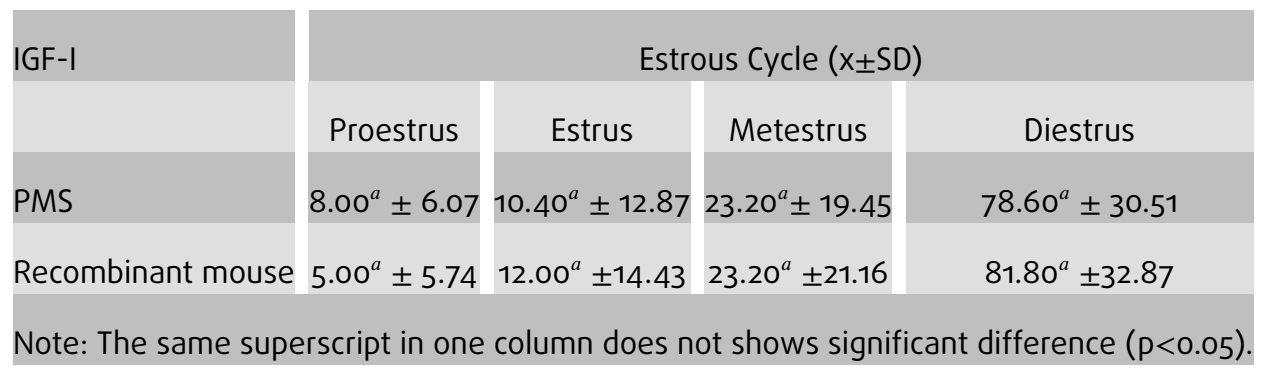

recombinant mouse causes metestrus phase period stay longer significantly $(p<0.05)$ in the $\mathrm{P}_{2}$ treatment, while diestrus phase period is significantly longer $(p<0.05)$ in the treatment of $\mathrm{P}_{4}$ and $\mathrm{P} 6$. The result of mice's vaginal smear in estrous cycle after given IGF-I PMS and IGF-I recombinant mouse is presented in Table 3.

Based on the result of vagina smear of mice in estrous cycle after given IGF-I PMS, there is no significant difference ( $p>0.05$ ) with the mice which have given IGF-I recombinant mouse.

The result of estrous cycle after vagina smear is shown by the existence of nucleated epithelial cells, gore epithelial cell, and leukocytes. Nucleated epithelial cells occured in proestrus phase; cornified epithelial cell occured in estrus phase, especially in vagina smear; in metestrus phase, many cornified epithelial cells and leukocytes are found; and in dietrus phase, there are many leukocytes are evenly found. Proestrus phase is a transition phase from diestrus to estrus in which the estrus symptom start to appear yet female animals do not accept mating from the males. This phase is marked by the growth of follicle into de Graaf follicle. The period is not significantly different ( $p>0.05$ ) toward all treatments: IGF-I PMS and IGF-I recombinant mouse.

Estrous is a transition phase from proestrus to metestrus. This phase is marked by the receipt male animals by females to do copulation. The period of this phase will be longer after given IGF-I PMS, while there is no significant difference ( $p>0.05$ ) by giving 

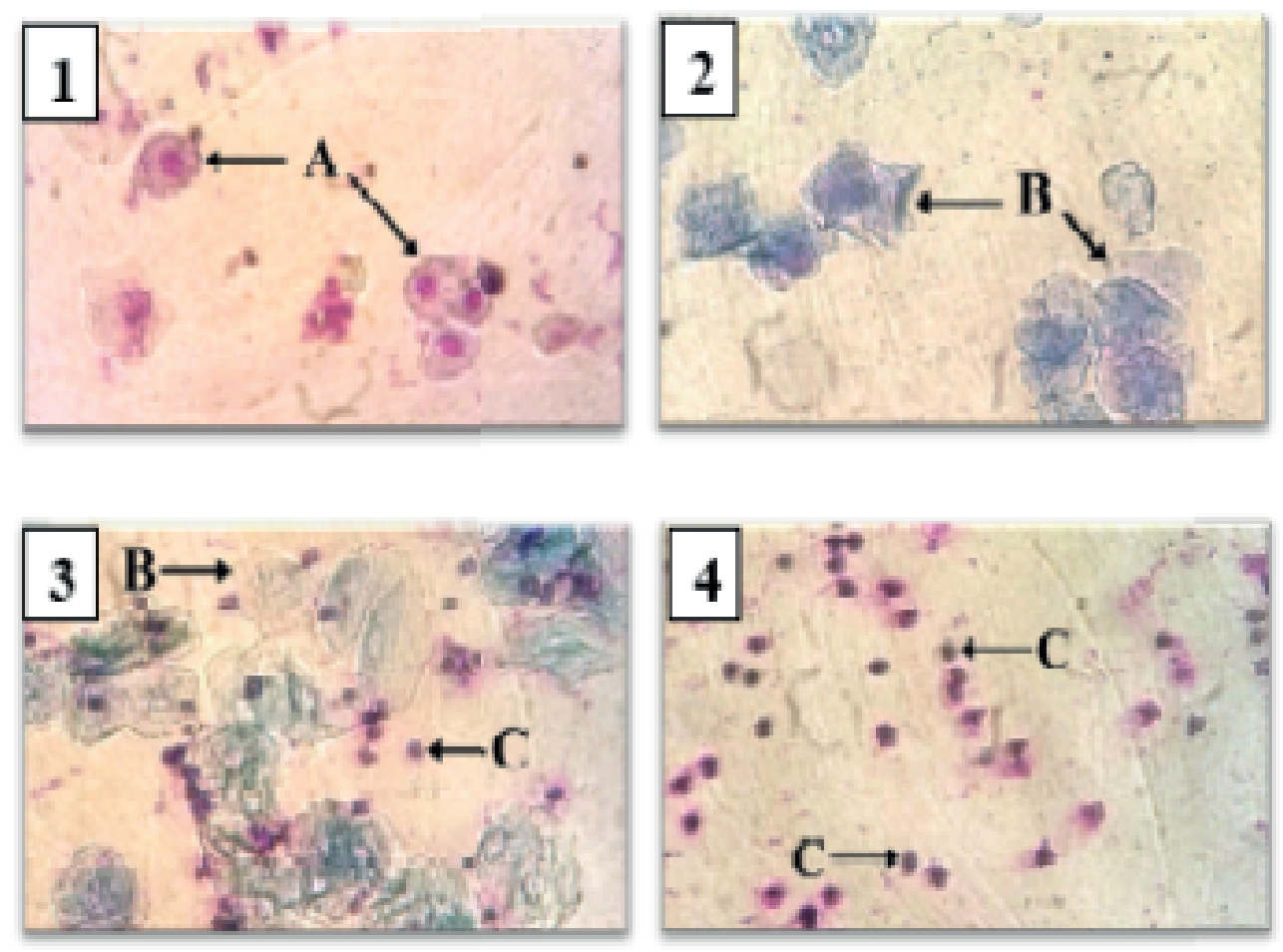

Figure 1: Cytology of mice's vaginal smear in proestrus phase, (A) nucleated epithelial cell, 2. Cytology of mice's vaginal smear estrous phase, (B) cornified cell, 3. Cytology of mice's vaginal smear in metestrus phase, (C) leukocyte cell, 4.Cytology of mice's vaginal smear in diestrus phase (Giemsa staining, 400x magnification).

IGF-I recombinant mouse. Adding IGF-I PMS shows a significant alteration on estrous phase $(p<0.05)$ in $\mathrm{T}_{3}$ handling with $40 \mathrm{ng} / \mathrm{ml}$ doses.

Metestrus is a transition phase from estrous to diestrus (luteal phase). This phase has high rate of estrogen which cause positive feedback from anterior pituitary to release LH. From this case, when LH is increasing, estrogen will be decreasing and pre-ovulatory will occur. The high rates of LH is the beginning of metestrus phase and followed by ovulation. Giving various doses of IGF-I PMS in this phase did not show significant difference ( $p>0.05$ ) comparing to Co. On the other hand, IGF-I recombinant mouse made metestrus phase goes longer significantly $(p<0.05)$ in T5 treatment and dose of $20 \mathrm{ng} / \mathrm{ml}$.

Diestrus is the phase after metestrus when the objects were given IGF-I PMS in the treatments of $T_{1}, T_{2}$, and $T_{3}$, the change of phase was longer yet there was no significant differences between the treatment ( $p>0.05$ ). Meanwhile, giving IGF-I recombinant mouse with the treatments of $\mathrm{T}_{4}$ and T6toward the objects showed that diestrus phase period is significantly longer $(p<0.05)$ comparing to Co (Table 2$)$. The change of diestrus phase is longer because of the high rates of progesterone level in the blood vessels. This progesterone level is produced by corpus luteum after ovulation. In other words, IGF-I PMS addition with various doses do not relieve the function of 
TABLE 4: The amount of mice litter sizes after given IGF-I PMS and IGF-I recombinant mouse subcutaneously.

\begin{tabular}{|c|c|c|}
\hline Treatment Doses & IGF-I Pregnant Crossbreed Mare Serum & IGF-I Recombinant Mouse \\
\hline Co & $3.80^{b} \pm 2.28$ & $3.80^{b} \pm 2.28$ \\
\hline $10 \mathrm{ng} / \mathrm{ml}$ & $5.40^{a b} \pm 1.67$ & $4.60^{a b} \pm 0.89$ \\
\hline $20 \mathrm{ng} / \mathrm{ml}$ & $7.40^{a b} \pm 1.95$ & $5.40^{a b} \pm 1.34$ \\
\hline $40 \mathrm{ng} / \mathrm{ml}$ & $8.40^{a} \pm 2.97$ & $7.80^{a b} \pm 3.03$ \\
\hline
\end{tabular}

progesterone in diestrus phase. Overall, domination of progesterone is the reason why diestrus phase period gets longer although adding IGF-I PMS can increase estrogen secretion.

The effect of giving IGF-I PMS and IGF-I recombinant mouse toward estrous cycle did not show significant difference ( $p>0.05$ ) based on the statistical result. This indicates mechanism work of either IGF-I PMS and IGF-I recombinant mouse have the same level of efficiency.

\subsection{The effect of IGF-I PMS and IGF-I recombinant mouse toward the amount of mice}

The result of giving IGF-I PMS and IGF-I recombinant mouse on female mice in this research subcutaneously showed good response toward the amount of mice litter. Monitoring result of mice litter will be presented in Table 4.

This research used ANOVA to analyze statistically toward the amount of mice litter by giving them IGF-I pregnant crossbreed mare serum rather than IGF-I recombinant mouse subcutaneously. The result is not significantly different $(p<0.05)$ and from this result it can be seen that giving IGF-I PMS subcutaneously has the same level of efficiency with IGF-I recombinant mouse toward the amount of mice litter.

The doses that are given in this research are various. With Co which contains $0.1 \mathrm{ml}$ of physiological $\mathrm{NaCl}$, the number of mice litter is fewer than if they are given IGF-I pregnant crossbreed mare serum and IGF-I recombinant mouse. By giving IGF-I PMS with doses of $T_{1} 10 \mathrm{ng} / \mathrm{ml}, \mathrm{T}_{2} 20 \mathrm{ng} / \mathrm{ml}$, and T3 $40 \mathrm{ng} / \mathrm{ml}$ consecutively, the obtained mice will increase with the numbers are follows: $5.40 \pm 1.67 ; 7.40 \pm 1.95 ; 8.40 \pm 2.97$. This shows that there are different results based on the doses given. An optimal result can be reached by giving dose of T3 $40 \mathrm{ng} / \mathrm{ml}$ of IGF-I PMS. In addition, giving IGF-I recombinant mouse provides different results as well, based on the doses given. Here 
are the numbers of obtained mice when IGF-I recombinant mouse is added: $4.60 \pm 0.89$; $5.40 \pm 1.34 ; 7.80 \pm 3.03$. It shows a good result in the dose of $T 640 \mathrm{ng} / \mathrm{ml}$. In this research, it can be seen that the number of mice in $\mathrm{T}_{3}$ is significantly different from group ofCo. Meanwhile, in the groups of $\mathrm{T}_{1}, \mathrm{~T}_{2}, \mathrm{~T}_{4}, \mathrm{~T}_{5}$, and $\mathrm{T} 6$ are not significantly different from Co although there is an enhancement of mice litter number here. This is due to some factors, such as the condition of female mice hormones, how the substance given, and the environmental factor. Moreover, the comparison result shows that there is no significant difference between IGF-I pregnant crossbreed mare serum and IGF-I recombinant mouse.

\section{Discussion}

\subsection{The effect of IGF-I PMS and IGF-I recombinant mouse on mice estrous cycle}

Estrous cycle is the sexual cycle which is happened in female animal. It is divided into two phases: follicular and luteal. Follicular is a phase where follicle develops until the outbreak of de Graaf follicle (ovulation). This phase causes proestrus and estrous symptoms. On the other hand, luteal is a phase after ovulation in which it is following the period of progesterone secretion and the phase of corpus luteum formation. This phase causes metestrus and diestrus symptoms [22]. This shows a connection between IGF-I PMS and hormonal condition on female mice, and its effect on estrous cycle.

Estrus phase, estrogen and LH reach the highest rate, while it reaches the lowest rate in diestrus phase [23]. Besides, the follicle size will be getting bigger. The bigger follicle size, the estrogen synthesis will increase as well [24]. Because the estrogen hormone increases, the period of estrous phase will be longer. According to [25], the long period of estrous phase will be important implication for mice reproduction because they have long mating. Moreover, long extension phase of estrous if they are given IGF-I PMS with T3 comparing to Co, it would be more benefit and has significant potential in terms of fertilization.

Metestrus phase according to [26], the high rates of estrogen causes vascularization from endometrium. Maximum vascularization occured in the end of the phase. It dropped down causing blood vessels are back to former position and it could be seen there are many ruptured capillaries thus leukocytes are found in vaginal smear. Diestrus is the phase after metestrus. This phase lasted 60-70 hours [27]. 


\subsection{The effect of IGF-I PMS and IGF-I recombinant mouse toward the amount of mice}

There are some factors that affect a variation number of mice litter in every treatment, such as the object, the given doses, the given IGF-I pregnant crossbreed mare serum and IGF-I recombinant mouse, and injection time. The animals that are used to be an object is really influential for research, especially for the hegemonity. It is because of different response of super ovulation female animals give, based on the species, life weight, lust cycle phase, age, parturition post interval, season, and feed [28]. There are might some differences in life weight and age of the objects of this research and this can affect their reproduction.

The use of both IGF-I pregnant crossbreed mare serum and IGF-I patent determines the number of maturated cow's oocyte. The raise of maturated oocyte percentage indirectly hands in hand with the percentage of embryo cleavage. Giving IGF-I also raises the number of pigs oocyte cleavage, fertilization, pro-nucleus formation, and embryo growth percentage at the stage of 8-cell. IGF-I supplementation can increase the amount of cows embryo in vitro by stimulating expansion or cumulus expansion, oxidative metabolism, maturation core, cleavage, and fertilization. In rabbits, giving IGF-I to their oocyte can increase maturation core $[16,29]$.

Insulin-like growth factor-I has important role in follicle growth, follicle growth dominant, and steroidogenesis. IGF-I will increase LH or human Chorionic Gonadotropin (hCG) stimulation will release androgen. FSH induces steroidogenesis and causes growth, also differentiates follicle cells as well. IGF-I maternal mediates the effect from FSH toward ovary and generates follicle growth in the beginning of pregnancy of mare type Thoroughbred. Estrogen can raise IGF-I plasma through IGF-I escalation from the liver or follicle. IGF-I level on follicle is positively connected with the diameter of cows' antral follicle during pregnancy [30]. Insulin-like growth factor-I and IGFBP-I are able to intensify embryo culture in vitro with something related to cell death reduction. Mediation arrangements in vivo by IGF-I, IGF-IR, and IGFBP-I called Intraovarian IGFIGFBP system have important role in process of follicle growth, oocyte maturation and ovulation, and embryo growth [31].

The level of IGF-I concentration on blood vessels of cattles which have not entered puberty will decrease and cause a delay of puberty. This is related to the lowering number of follicle growth and it can undermine the ability of ovary in producing estradiol, so that it will postpone LH stimulation [32]. Stated of [33] that adding IGF-I toward heifer is signed as the possibility of puberty occurence when somatic grows as 
planned. IGF-I in granulosa cells and theca cells from ovary follicle stimulates receptor cells type I. Afterwards, in autocrine manner, IGF-I will stimulate the proliferation and diferentiation of granulosa cells. While in paracrine infusion, IGF-I will stimulate steroid secretion (stereidogenesis) from ovary by raising androstendion and estradiol production. This indicates that IGF-I works by affecting steroid production in granulosa cells and theca cells in ovary follicles. The escalation of androstendione and estradiol production affects anterior pituitary to increase LH secretion (feedback positive). The raising of LH production (LH abundant) causes the increasing of bloodstream into ovary. With the help of enzyme (ovulatory lytic enzym), follicle will rupture and ovulation happens.

\section{Conclusion}

The addition of insulin-like growth factor-I(IGF-I) derived from pregnant crossbred mare serum (PMS) can extend estrous phase in estrous cycle and increase the amount of mice litter sizes (Mus musculus). Giving IGF-I PMS will affect as well as giving IGF-I recombinant mouse toward estrous cycle (proestrus, estrus, metestrus, and diestrus phase) and the amount of mice litter (Mus musculus). IGF-I pregnant crossbred mare serum and IGF-I recombinant mouse are interchangeable or just as good.

\section{References}

[1] G. Oberlender, L.D.S. Murgas, M.G. Zangeronimo, A.C. da Silva, T.A. Menezes, T.P. Pontelo, L.A. Vieira, Role of Insulin-Like Growth Factor-I and Follicular Fluid from Ovarian Follicles with Different Diameters on Porcine Oocyte Maturation and Fertilization In Vitro. Theriogenology 80 (2013) 319-327.

[2] J.A. Neira, D. Tainturier, M.A. Pen., J. Martal, Effect of The Association of IGF-I, IGF-II, bFGF, TGF-b1, GM-CSF, and LIF on The Development of Bovine Embryos Produced InVitro. Theriogenology73 (2010) 595-604.

[3] S. Singhal, S. Prasad, B. Singh, B., J.K. Prasad, and H.P. Gupta, Effect of Including Growth Factors and Antioxidants in Maturation Medium used for In Vitro Culture of Buffalo Oocytes Recovered In Vivo. AnimReprod Sci. 113 (2009) 44-50.

[4] D.M. Magalhães-Padilhaa, A.B.G. Duarte, V.R. Araújo, M.V.A. Saraiva, A.P. Almeida, G.Q. Rodrigues, M.H.T. Matos, C.C. Campello, J.R. Silva, and M.O. Gastal, Steady-State Level of Insulin-Like Growth Factor-I (IGF-I) Receptor mRNA and The Effect of IGFI on The In Vitro Culture of Caprine Preantral Follicles. Theriogenology 77 (2012) 
206-213.

[5] W.M.M. Nalley, R. Handarini, M. Rizal, R.I. Arifiantini, T.L. Yusuf and B. Purwantara, Determination ofThe Estrous Cycle Based on Vaginal Cytology and Hormone Profile in Timor Hind. Jurnal Veteriner 12(2) 2011, 98-106.

[6] A. Inoue, T. Sakae, and T. Sumio, Insulin-Like Growth Factor-I Stimulated DNA Replication in Mouse Endometrial Stroma Cells. J. Reprod and Development 51 (2005) 3.

[7] C. Sumantri, M. Imron, Sugyono, E. Andreas, R. Misrianti, and A.B.L. Ishak, Growth Hormone Gene Family (GH, GHR, GHRH and Pit-1) Polymorphisms and Its Association with Superovulation Response, Ovulation Rate, Fertilization Rate and Embryo Quality in Embryo Transfer Station (BET) of Cipelang. JITV16(2) 2011, 126139.

[8] M.A. Velazquez, M. Newman, M.F. Christie, P.J. Cripps, M.A. Crowe, R.F. Smith, and $H$. Dobson, The Usefulness of A Single Measurement of Insulin-Like Growth Factor1 as A Predictor of Embryo Yield and Pregnancy Rates in ABovine MOET Program. Theriogenology 64 (2005) 1977-1994.

[9] R.A. Cushman, V.S. Hedgpeth, S.E. Echternjkamp, and J.H. Britt, Evaluation of Numbers of Microscopic and Macroscopic Follicles in Cattle Selected for Twinning. J.Anim.Sci. 78 (2000) 1564-1567.

[10] F.D. Jousan, and P.J. Hansen, Insulin-Like Growth Factor-I Promotes Resistance of Bovine Preimplantat Ion Embryos to Heat Shock Through Actions Independent of Its Anti-Apoptotic Actions Requiring Pl3K Signaling. Mol.Reprod.Dev. 74 (2007) 189196.

[11] J. Block, C. Wrenzycki, H. Niemann, D. Herrmann, and P.J. Hansen, Effects of InsulinLike Growth Factor-1 on Cellular and Molecular Characteristics of Bovine Blastocyst Produced In Vitro. Mol.Reprod. Dev. 75 (2008) 895-903.

[12] G.A. Hendarti, Pengaruh Pemberian Kompleks Insulin-Like Growth Factor-I dan Insulin-Like Growth Factor Binding Protein-3 terhadap Perbaikan Reproduksi Mencit Betina (Mus musculus) [Tesis]. Program Pasca Sarjana. Universitas Airlangga, 2006.

[13] M.M. Rochler, Insulin-Like Growth Factor Binding Protein, Vitamins and Hormones 47 (1993) 111-114.

[14] T.R. Davidson, C.S. Chamberlain, T.S. Bridges, and L.J. Spicer, Effect of Follicle Size on In Vitro Production of Steroids and Insulin-Like Growth Factor (IGF)-I, IGF-II, and The IGF-Binding Proteins by Equine Ovarian Granulosa Cells. Biology Reproduction 66 (2002) 1640-1648. 
[15] J.D. Wilson, D.W. Foster, M.K. Hendry, and P.R. Larsen, Endocrine Disease. William Text Book of Endocrinology $9^{\text {th }}$ ed. W.B. Founder Saunders Company, 1998. 14371452.

[16] T.I. Restiadi, Potensi Biologis Bahan Bioaktif Insulin-Like Growth Factor-I Asal Serum Kuda Crossbred G3-G4 Bunting pada Fertilisasi In Vitro pada Sapi (Disertasi). Universitas Airlangga, 2013.

[17] Y. Wang, S. Nishida., H.Z. Elalieh., R.K. Long., B.P. Halloran., and D.D. Bikle, Role of IGF-I Signaling in Regulating Osteoclastogenesis. J. Bone and Mineral Research. 21 (2006) 123-128.

[18] G.N. Arunakumari, N. Shanmugasundaram, and V.H. Rao, Development of Morulae from The Oocytes of Cultured Sheep Preantral Follicles. Theriogenology 74 (2010) 884-894.

[19] Rintafiani, Siklus Estrus pada Mencit (Mus musculus) [Skripsi]. Program Pendidikan Biologi. Fakultas Matematika dan Ilmu Pengetahuan Alam. Institut Teknologi Sepuluh Nopember. Surabaya, 2014.

[20] G.C. Agustina, Pengaruh Pemberian Ekstrak Daging Buah Pare Hijau (Momordica chaantia L.) terhadap Siklus Birahi Mencit (Mus musculus) yang Disuperovulasi dengan PMSG dan hCG [Skripsi]. Fakultas Kedokteran Hewan. Universitas Airlangga. Surabaya, 2013.

[21] R.G.D. Steel, and J.H. Torrie, Principles and Procedures of Statistics, McGraw. Hill Co., New York, 2013, 137-269.

[22] E.S.E. Hafez, Reproduction in Farm Animal. $7^{\text {th }}$ ed. Lippincott Williams \& Wilkins, 2000, 48-52, 59-62, 68-80, 90-94, 196-200.

[23] L.A. Sutasurya, A.J. Sitasiwi, dan K. Ratnawati, Penentuan Kandungan Estradiol $\left(E_{2}\right)$ dan Luteinizing Hormone (LH) pada Petaurus breviceps papuanus (Marsupialia) selama Satu Siklus Estrus. Jurnal Sains dan Teknologi Nuklir Indonesia. 11 (2001) 25-35.

[24] M.H. Johnson, and B.J. Everitt, Essential Reproduction. $2^{\text {nd }}$ ed. Blackwell Scientific Publications.London, 1984.

[25] J.C.L. Tou, R.E. Grindeland, and C.E. Wade. Effect of Diet and Exposure to Hindlimb Suspension on Estrous Cycling in Sprague-Dawley Rats. Am.J.Endrocrinol.Metab, 2003, 286.

[26] Ismudiono, P. Srianto, H. Anwar, S.P. Madyawati, A. Samik, dan E. Safitri, Buku Ajar Fisiologi Reproduksi pada Ternak. Airlangga University Press.Surabaya, 2010.

[27] C.D. Turner, dan J.T. Bagnara, Endokrinologi Umum. Edisi ke-6. Airlangga University Press. Surabaya, 1998, 564-607. 
[28] P.P. Putro, Transfer Embrio pada Sapi. Fakultas Kedokteran Hewan, Universitas Gajah Mada. Yogyakarta, 2001.

[29] B.R. Lackey, S.L.L. Gray, and D.M. Henricks, Physiological Basis for Use of Insulin-Like Growth Factor in Reproductive Applications: A Review. Theriogenology 53 (2000) 1147-1156.

[30] R.I. Derar, S. Haramaki, M.D.S. Hoque, T. Hashizume, T. Osawa, K. Taya, G. Watanabe, and Y.I. Miyake, 2005. Insulin-Like Growth Factor-I as A Follicular Growth Promoter during Early Pregnancy in Thoroughbred Mares. Vet. Med. Sci., 2005.

[31] T.C. Lin, J.M. Yen, K.B. Gong, T.T. Hsu, and L.R. Chen, IGF-I/IGFBP-I Increases Blastocyst Formation and Total Blastocyst Cell Number in Mouse Embryo Culture and Facilitates The Establishment of AStem-Cell Line. BMC Cell Biology 4 (2003) $14-19$.

[32] M.A. Velazquez, L.J. Spicer, and D.C. Wathes, The Role of Endocrine InsulinLike Growth Factor-I (IGF-I) in Female Bovine Reproduction. Domestic Anim.Endocrinol.35 (2008) 325-342.

[33] J.V. Yelich, R.P. Wettemann, T.T. Marston, and L.J. Spicer, Luteinizing Hormone, Growth Hormone, Insulin-Like Growth Factor-I, Insulin and Metabolites before Puberty in Heifers Fed to Gain at Two Rates. Domest.Anim.Endocrinol 13 (1996) $325-38$. 